\title{
Animal Health and Welfare in Organic Sheep and Goat Farming - Experiences and Reflections from a Swedish Outlook
}

\author{
By Åsa Lindqvist \\ Swedish Animal Health Service, Box 932, S-391 29 Kalmar.
}

\begin{abstract}
Introduction
There are different ways to assemble data in order to get a picture of animal health: registrations made by the farmer, veterinary treatments, lamb growth, milk production, meat inspections, carcass weights and conformations. Most data though don't distinguish between organic and conventional production. Up to this time, the best way to get a picture of animal health in organic production, and to compare it with conventional production or even better with the ideal animal health, has been through projects and epidemiological research. The exchange of experience between veterinarians, advisors, KRAV inspectors etc has been and is worth-while.

Swedish Animal Health Service has run four projects on animal health in organic production. Three of them concern internal parasites in organic sheep flocks. The aim of the fourth is to identify health problems and suggest a model for health control in organic production of beef cattle, swine and sheep. This paper presents the author's own experiences and reflections from her work with organic sheep farming in Sweden.
\end{abstract}

\section{Key words}

Data collection, health registrations, veterinary treatments, lamb growth, milk production, meat inspections, carcass weights and conformations, projects, flock visits, future measurements.

\begin{abstract}
Definitions
Animal welfare of an individual is defined by Broom (1986) as its state as regards its attempts to cope with its environment. Effects on welfare which can be described include those of disease, injury, starvation, housing conditions, veterinary treatment etc (Broom 1996). Referring to Broom, animal health could thus be an effect of animal welfare. But as far as I can see, animal health can also be regarded on as a matter per se, with or without effects on animal welfare. Since animal welfare is discussed by Karl Erik Hammarberg, I intend to speak mostly of sheep and goat health.
\end{abstract}

\section{Sources of data on animal health}

There are different ways, more or less precise, to assemble data on animal health, e.g.:

- Health registrations on the farm

- Veterinary treatments

- Lamb growth

- Milk production

- Meat inspections

- Carcass weights and conformations

- Projects; epidemiological research

- Synthesise knowledge and experience from veterinarians, advisors etc.

Though all these opportunities, it is at the present point of time difficult to get a true picture of animal health in organic sheep flocks. I hope though, that the meeting in Iceland will involve exchange of knowledge and experience from 
veterinarians who are working with organic production in the Nordic countries.

\section{A Swedish outlook}

Almost $9 \%$ of the arable land in Sweden is converted to organic production, about half of it is KRAV-certified. (KRAV and Demeter are the organisations in Sweden which set and certify standards for organic agriculture. Only KRAVor Demeter-certified products are allowed to be sold as organically produced.)

8200 sheep flocks with 194000 winter fed ewes are officially registered in Sweden (SCB 2000). We have about 150 flocks with dairy or mohair goats. There are no official figures on how many organic farms that hold sheep or goats, but they should be many more than the KRAVcertified flocks. 329 sheep flocks and 15 goat flocks are registered for inspection with KRAV.

\section{Health registrations}

Farmers with KRAV-certified flocks should keep health records of all injuries and illness, their treatment (including prophylactic treatments) and its result. Reports from slaughter, live inspection, milk test or equivalent shall be entered or well compiled and easily available.

These data have not been assembled or processed.

$33 \%$ of the sheep farmers registered at KRAV have joined the Sheep Health Service which include about 1500 farmers. The symptoms and diseases most frequently reported to the Sheep Health Service are coughing/pneumonia, diarrhoea, internal parasites, cobalt-/copper deficiency and abortion. These records don't distinguish between organically or conventionally reared sheep.

$43 \%$ of sheep farmers who are registered at $\mathrm{KRAV}$, have joined the control programme for Maedi-Visna, and 8 of the goat flocks are registered to the control programme for CAE.

\section{Veterinary treatments}

Practitioners send registrations from the farm visits to a central database, including diagnoses, treatments, vaccinations, blood-sampling etc. These registrations do not include whether the animal is organically or conventionally reared, thus preclude the possibility to compare veterinary treatments in different types of production.

\section{Lamb growth}

Farmers who have joined the Official Sheep Recording Scheme may weigh their lambs when they are about 110 days old. The weights and other data are assembled and statistically processed in order to get comparative figures. $23 \%$ of the KRAV-registered sheep flocks were 1999 registered in the Official Sheep Recording Scheme, half of these have weighed their lambs. Without any statistical analyses, these flocks seem to have about the same weights than the others in the Official Sheep Recording Scheme.

\section{Milk production}

Since there are only a few KRAV-registered milk goat flocks, and some of them are CAE-infected and others not, it is not relevant to compare figures of production in organic with conventional goat-flocks.

\section{Meat inspection}

In 1997 the Swedish University of Agriculture studied figures from meat inspection of organically and conventionally produced animals (Hansson et al. 2000). Concerning sheep and lambs, there were a low percentage of pneumonia, pleuritis and other registrations. The incidence of distomatosis was higher among lambs (4.9\%) and sheep (17.2\%) which were slaughtered as KRAV-certified (4 724) compared to conventionally produced $(4.2 \%$ resp. $7.6 \% ; 189$ 499). 
Slaughter weights, carcass confirmations Higher proportion (73\%) of lambs slaughtered in 1999 as KRAV-certified reached the best quality ("butikslamm") compared to lambs which were slaughtered as conventionally produced (65\%) (data from Swedish Meats). Note that the figures count for "slaughtered as KRAV-certified" - the organic farmer is able to choose if his/her lambs are going to be slaughtered as KRAV- or as conventionally produced lambs. If, for example, the farmer wants to have the lambs slaughtered within the withdrawal period for anthelmintics, or he doesn't expect the lambs to be of the best quality, which is necessary for getting the higher price for KRAVlambs, he/she can choose to have them slaughtered as conventionally reared lambs. On the other hand, sometimes the KRAV-producers have difficulty in getting their lambs slaughtered as KRAV-lambs when the lambs have reached the optimal weight and carcass confirmation, due to market conditions.

\section{Projects; epidemiological research}

The Swedish University of Agriculture run studies on lambs grazing Lotus corniculatus and the effect on internal parasites (SLU 1998). Up till now there have been four projects run by Swedish Animal Health Service with funds from Swedish National Board of Agriculture: three on internal parasites in organic sheep flocks and one on health problems. One of the projects was a three years study on internal parasites in 150 organic sheep flocks, representing different geographic parts of Sweden. The most important result was that almost one third of the flocks was infected with Haemonchus contortus. The result points out that it is very difficult, at least in Sweden, to produce lambs without hazardous parasite burdens, unless it is allowed to drench the ewes before the grazing season starts. It is also important to offer the lambs parasite-free grazing in the springtime and after weaning. The results will be published in Acta veterinaria scandinavica.

The other two projects are running the first year of two and include studies on internal parasites in organic sheep flocks with lambing in JuneJuly and alternate grazing with cattle.

The study on health problems in organic sheep flocks will be summarised next year. So far, 37 farms with organic sheep production have been visited. At each visit data on production, health problems, feeding etc are noted. Since I am responsible for this study and have made all the visits myself, my experience from organic sheep production is mainly from these visits.

About half of the flocks were registered to Sheep Animal Health Service. The most often registered health problems were haemonchosis, diarrhoea, high lamb mortality and lean ewes. Half of the flocks had joined the control programme for maedi-visna, one in the other half was infected with maedi-visna virus. In spite of sufficiently big enough grazing area and parasite free spring pasture, the parasite situation was not good - several of the flocks had Haemonchus infections and had to drench the sheep.

Four farmers had sent in samples from silage/hay for analyses (protein, energy etc). Half of them gave the sheep access to no minerals or inappropriate minerals. The mean figures for lambing and weighed lambs percentage were lower for organic flocks than conventional. Mean lamb mortality was equal to the figures of flocks in the Official Sheep Breeding Scheme, and varied from 3 to $36 \%$. The growth rate up to slaughter was lower for organic lambs. The carcass quality and conformation were good.

Half of the farmers were skilful, eager to learn more and had a defined goal with their production. On the other farms there could be problems due to the demand for letting sheep and lambs have access to outdoor environment in 
wintertime. Farmers often keep ewes in high pregnancy, ewes with young lambs and winterlambs at the same time. Different nutritional requirements demand opportunity to keep sheep and lambs in different groups, which often is impossible if all groups should have access to outdoor areas. Also having parasite-free spring pasture or pens in mind, this crucial problem is not given to everyone to have practical solution of. A couple of farmers underfed their sheep, not only because they didn't keep the sheep in different feeding groups - the amounts of concentrates were not adjusted to high litter sizes.

So far, I can summarise that the most important health problems are connected with feeding and internal parasites. I don't think there are more or other problems in organic flocks than in conventionally, but the problems will be more stressed in the organic flocks. For example, in a conventionally reared flock the farmer is able to feed high rations of concentrates if the silage or hay has low energy- or protein levels. Also parasitism can be a hidden problem in conventionally reared flocks due to routine drenching.

\section{Are organic producers interested in keeping a high standard of animal health?}

Unfortunately not all of them. The reason for this may be found in the motives for a farmer to convert to organic production. I take the liberty of divide them into three groups:

1. The farmer who converts due to ethic reasons, mixed with good sense and knowledge. He/she is interested to learn, seek advice and information. He/she aims for a top-production in all respects.

2. The "religious" farmer who often has a romantic picture of naturally living, unfortunately not always combined with good sense or good animal health. This farmer is often interested in the use of herbs, homeopathics etc. and doesn't trust in veterinarians and established medicine sciences.
3. The farmer who converts for economical reasons. $\mathrm{He} / \mathrm{she}$ is not interested in high animal health level if it cannot be counted in money. No ethics, short-sighted maximum economical profits. Often the worst to deal with but fortunately short-lived as organic producer. It is my idea that, with regards to the veterinarian's contact with the farmer, the problems with organic production is of informative, educational and psychological nature. There is a big lack of information and advice. Organic production per se is not a guarantee for good animal health. Even a "bad" farmer is allowed to get subsidies for organic production.

Good animal welfare and health conditions should be a fact in all animal farming, and maybe more in organic farming. I am not convinced neither that the organic farmers have a higher nor a lower standard. The problem is that we don't get into contact with the bad ones. This is the case particularly with the organic farmers who have not joined KRAV.

The restriction of using allopatic treatments in organic flocks will enforce rigorous control of and advice on animal health and welfare. Consequently, an absolute condition is that there will be economical support for this.

\section{Future measures}

In order to care for animal health and welfare, I would like to suggest that

- all organic farmers should join a health service programme. This should include a visit by a veterinarian before the flock is KRAVregistered in order to help the farmer with a grazing plan, feeding plan, to check the inand outdoor environment with regards to infectious diseases, parasites etc. The veterinarian's opinion should be regarded in the approval of KRAV registration. 
- it should be allowed to treat ewes with anthelmintics after lambing but before moving out on pasture, in order to prevent hazardous parasite problems.

- the organic sheep and goat flocks should join the control programmes for maedi-visna and CAE respectively.

- it is necessary to find effective ways of assembling data of production results, diseases, veterinary treatments etc and to discriminate between organic and conventional flocks in the data base.

- future research includes management, feeding, grazing systems and internal parasites in organic production.

- there should be means of co-operation with the certifying organisation, inspectors, advisors, veterinarians, meat inspectors etc.

- a network for veterinarians who are working with organic production in the Nordic countries would be established.

- there must be financial support for control of animal health and welfare in organic production and for advice to organic farmers.

\section{References}

Broom DM: Indicators of poor welfare. Br. Vet. J. 1986, 142, 524-526.

Broom DM: Animal welfare defined in terms of attempts to cope with the environment. Acta Agric. Scand.1996, Sect A, Animal Sci. Supplementum 27, 22-28 .
Hansson I, Hamilton C, Forslund K, Ekman T: En jämförelse av slaktresultat mellan KRAVuppfödda och konventionellt uppfödda djur (A study of carcass quality - certified organic compared with conventionally raised livestock). Sv. Vet. tid. 2000, Supplement 29,17-24

$S L U$ : Ekologiskt Lantbruk. Forsknings- och utvecklingsprojekt, försöksgårdar och skoljordbruk i Sverige 1998. Centrum för Uthålligt Lantbruk.

SCB: Jordbruksstatistisk årsbok 2000 (Agricultural Statistics Yearbook 2000).

\section{Sammanfattning}

Djurhälsa och djuromsorg i ekologiska får- och getbesättningar. Erfarenheter och reflexioner från en svensk horisont.

För att få en bild av djurens hälsa kan data samlas från olika källor: djurägarens noteringar, veterinärbehandlingar, lammtillväxt, mjölkproduktion, köttbesiktning, slaktvikter och klassning vid slakt. De flesta data skiljer dock inte mellan ekologisk och konventionell produktion. Fram tills nu har det bästa sättet att få en bild av djurhälsan i ekologisk produktion, och att jämföra den med djurhälsan i konventionell produktion eller ännu hellre med den ideala djurhälsan, varit via projekt och epidemiologisk forskning. Utbyte av erfarenheter mellan veterinärer, rådgivare, KRAV-kontrollanter etc har varit och är värdefullt. Svenska Djurhälsovården har genomfört fyra projekt angående djurhälsa i ekologisk produktion. Tre av dem omfattar inälvsparasiter i ekologiska fårbesättningar. Syfte med det fjärde projektet är att identifiera hälsoproblem och föreslå modell för hälsokontroll för ekologisk produktion av köttdjur, svin och får. Detta föredrag presenterar författarens egna erfarenheter och reflexioner från sitt arbete med ekologiska fărbesättningar i Sverige. 